\title{
Hereditary pancreatic cancer
}

\author{
Kodai Abe ${ }^{1} \cdot$ Minoru Kitago ${ }^{1} \cdot$ Yuko Kitagawa $^{1} \cdot$ Akira Hirasawa $^{2}(0$
}

Received: 4 June 2021 / Accepted: 17 August 2021 / Published online: 2 September 2021

(c) The Author(s) 2021

\begin{abstract}
Pancreatic cancer is associated with both family and hereditary cancer syndromes. Multigene panel testing for pancreatic cancer detected the germline variants BRCA1/2, PALB2, ATM, TP53, MLH1, STK11/LKB1, APC, CDKN2A, and SPINK1/ $P R S S 1$ as high-risk genes. A latest genome-wide association study revealed the common, but low-risk germline variants in pancreatic cancer patients. Active pancreatic surveillance using magnetic resonance imaging and endoscopic ultrasound is recommended for high-risk individuals who have a family history of pancreatic cancer or harbor these germline pathogenic variants to improve the detection rate and prognosis of pancreatic cancer. Since poly-ADP-ribose polymerase (PARP) inhibitor has been shown to be effective in improving the prognosis of BRCA-positive pancreatic cancer as well as hereditary breast and ovarian cancer syndrome, PARP inhibitor therapy is currently being applied as precision medicine to pancreatic cancer patients harboring the BRCAl/2 germline variant. This review highlights the importance of surveillance for germline pathogenic variants in pancreatic cancer and is expected to lead to improvements in the diagnosis and prevention of pancreatic cancer as well as facilitate the development of effective therapeutic strategies and precision medicine.
\end{abstract}

Keywords Cancer predisposition gene $\cdot$ Familial pancreatic cancer $\cdot$ Hereditary pancreatic cancer $\cdot$ Multigene panel testing $\cdot$ Surveillance

\section{Introduction}

Pancreatic cancer is a multifactorial genetic disease. There are known germline pathogenic variants associated with hereditary pancreatic cancer, which is closely related to other hereditary tumor syndromes. Several high-risk factors have been identified, including family history of pancreatic cancer [1]. These risk factors are divided into modifiable, including smoking, daily alcohol consumption, chronic pancreatitis, diet, and obesity; and nonmodifiable, including age, gender, ethnicity, ABO blood group, diabetes, and family history (Fig. 1) [2-4]. Familial pancreatic cancer is defined as having two or more first-degree relatives (FDRs) with pancreatic cancer and accounts for approximately 3\%-8.4\%

Akira Hirasawa

hir-aki45@okayama-u.ac.jp

1 Department of Surgery, Keio University School of Medicine, Tokyo, Japan

2 Department of Clinical Genomic Medicine, Graduate School of Medicine, Dentistry and Pharmaceutical Sciences, Okayama University, 2-5-1 Shikata-cho, Kita-ku, Okayama 700-8558, Japan of all cases of this disease [5, 6]. Genome sequencing analysis is used to investigate the germline variants of pancreatic cancers. In addition, genome-wide association analysis has identified common single nucleotide variants (SNVs) that are more frequently detected in pancreatic cancer.

Germline variant data can support early detection, prevention, and personalized treatment of pancreatic cancer. Here, we highlight the most recently identified germline variants in pancreatic cancer, current management strategies, and future perspectives for improving prognosis.

\section{Hereditary pancreatic cancer related genes}

Genes associated with hereditary cancer plays a key role in the development of pancreatic cancer [7-10]. The relationship between various hereditary cancer syndromes and pancreatic diseases is shown in Table 1. These pancreatic diseases can serve as prognostic determinants for each hereditary cancer syndrome. 
Fig. 1 Relative risk and incidence of risk factors for pancreatic cancer. Pancreatic cancer has multiple mixed risk factors, including modifiable and nonmodifiable factors. These risk factors correlate with germline pathogenic variants. Very rare, but extremely high-risk germline variants (STK11/LKB1, TP53, and PRSS1/SPINK1) are usually detected using family linkage analysis, and rare and high-risk germline variants $(B R C A 1 / 2$, ATM, PALB2, CDKN2A, MLH1, and $A P C)$ are detected using multigene panel testing. Common low-risk germline variants $(G P 2$, and $N O C 2 L)$ are detected using genome-wide associated studies

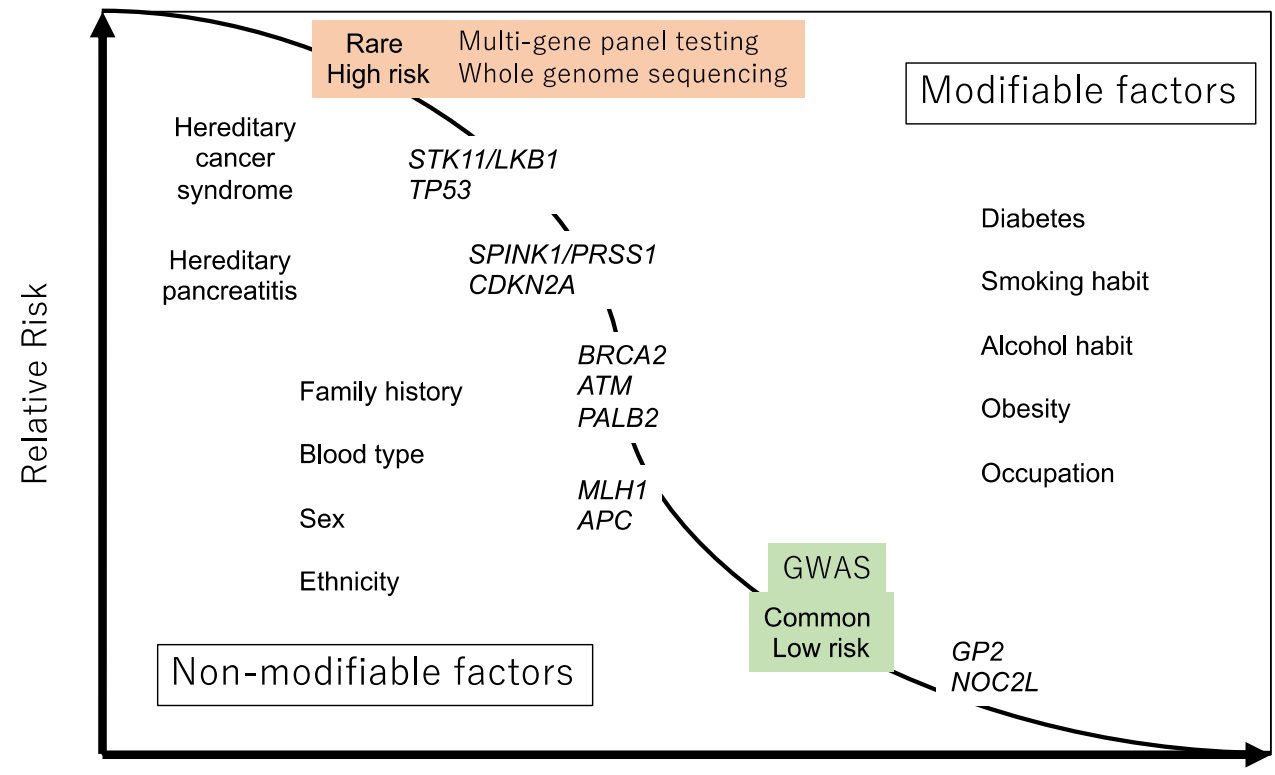

Frequency / Incidence

\section{BRCA1/2}

$B R C A 1$ and $B R C A 2$ are associated with hereditary breast and ovarian cancer syndrome (HBOC). HBOC follows an autosomal dominant pattern of inheritance and is characterized by early-onset breast and ovarian cancers. BRCA1/2 are DNA damage repair genes whose monoallelic or biallelic variants can cause HBOC or Fanconi anemia, respectively $[11,12]$. Pathogenic BRCA carriers should undergo surveillance for breast, ovarian, prostate, and pancreatic cancer as well as melanoma. The incidence of germline BRCA1/2 pathogenic variants in pancreatic cancer is 5\%-9\% [13]. Moreover, the relative risk (RR) and cumulative incidence of pancreatic cancer for germline BRCA2 pathogenic variants are 3.5-10 and $2 \%-7 \%$, and for germline $B R C A 1$ pathogenic variants, 2.26 and $1 \%-3 \%$, respectively [14].

\section{PALB2}

PALB2 (partner and localizer of BRCA2) is also involved in DNA damage repair and Fanconi anemia, which is strongly associated with breast, ovarian, and pancreatic cancer $[15,16]$. PALB2 pathogenic germline variants are associated with a $7.18,2.91$, and $2.37 \mathrm{RR}$ of developing female breast, ovarian, and pancreatic cancer, respectively, and their estimated incidence up to age 80 years is $53 \%$, $5 \%$, and $2 \%-3 \%$, respectively [17]. The latest American College of Medical Genetics and Genomics guidelines recommend that pancreatic cancer surveillance should be considered for germline PALB2 pathogenic variant [18].

\section{ATM}

ATM, whose biallelic variant can cause Ataxia-telangiectasia, plays a role similar to that of $B R C A 1 / 2$ in DNA damage repair [19]. The ATM pathogenic germline variant is strongly associated with breast, ovarian, prostate, and pancreatic cancer. The $\mathrm{RR}$ for pancreatic cancer is 2.41 in individuals with the ATM germline pathogenic variant [20].

\section{NBN}

$N B N$ is a DNA damage response gene, whose biallelic variant can cause severe microcephaly, infertility, and cancer. $N B N$ pathogenic variants are mostly reported in breast cancer, but recent reports link them to pancreatic cancer as well. However, the cumulative incidence or RR has not been reported [16, 21].

\section{TP53}

The TP53 pathogenic variant is known to cause Li-Fraumeni syndrome, which is associated with a high risk of developing adrenocortical carcinomas, hematopoietic malignancies, breast cancer, central nervous system tumors, osteosarcomas, and soft-tissue sarcomas (https://www.ncbi.nlm.nih.gov/books/ NBK1311/). The TP53 germline variant is associated with pancreatic cancer with RR of 7.3 [22]. 
Table 1 Relationship between germline variants and pancreatic diseases

\begin{tabular}{|c|c|c|c|c|c|c|}
\hline Gene & $\begin{array}{l}\text { Hereditary cancer } \\
\text { syndrome }\end{array}$ & Pancreatic disease(s) & $\begin{array}{l}\text { Relative risk } \\
\text { for pancreatic } \\
\text { cancer }\end{array}$ & $\begin{array}{l}\text { Cumulative incidence } \\
\text { of pancreatic cancer } \\
(\%)\end{array}$ & Phenotype & References \\
\hline$B R C A 1$ & \multirow{2}{*}{$\begin{array}{l}\text { Hereditary breast } \\
\text { and ovarian cancer } \\
\text { syndrome }\end{array}$} & \multirow[t]{2}{*}{ Pancreatic cancer } & $2.26-3$ & $1-3 \%$ (life-time risk) & \multirow{2}{*}{$\begin{array}{l}\text { Breast, ovarian, and } \\
\text { prostate cancer }\end{array}$} & \multirow[t]{2}{*}[13,14]{} \\
\hline$B R C A 2$ & & & $3.5-10$ & 2-7\% (life-time risk) & & \\
\hline$P A L B 2$ & - & $\begin{array}{l}\text { Pancreatic can- } \\
\text { cer Intraductal } \\
\text { papillary mucinous } \\
\text { neoplasm }\end{array}$ & 2.37 & $\begin{array}{l}2-3 \% \text { (up to } 80 \text { years } \\
\text { of age) }\end{array}$ & $\begin{array}{l}\text { Breast, ovarian, and } \\
\text { prostate cancer }\end{array}$ & {$[15,17]$} \\
\hline$A T M$ & - & Pancreatic cancer & 2.41 & N.D & $\begin{array}{l}\text { Breast, ovarian, and } \\
\text { prostate cancer }\end{array}$ & [18] \\
\hline$N B N$ & - & Pancreatic cancer & N.D & N.D & $\begin{array}{l}\text { Breast, ovarian, and } \\
\text { prostate cancer }\end{array}$ & [15] \\
\hline TP53 & - & Pancreatic cancer & 7.3 & N.D & $\begin{array}{l}\text { Adrenocortical car- } \\
\text { cinoma } \\
\text { Breast cancer } \\
\text { Central nervous } \\
\text { system tumor } \\
\text { Osteosarcoma } \\
\text { Soft tissue sarcoma }\end{array}$ & {$[21]$} \\
\hline$M L H 1$ & \multirow[t]{4}{*}{ Lynch syndrome } & \multirow[t]{4}{*}{ Pancreatic cancer } & 7.8 & $\begin{array}{l}6.2 \% \text { (up to } 75 \text { years } \\
\text { of age) }\end{array}$ & \multirow{4}{*}{$\begin{array}{l}\text { Colorectal, gastric, } \\
\text { and endometrial } \\
\text { cancer }\end{array}$} & \multirow[t]{4}{*}[24]{} \\
\hline MSH2 & & & 0.6 & $\begin{array}{l}0.5 \% \text { (up to } 75 \text { years } \\
\text { of age) }\end{array}$ & & \\
\hline MSH6 & & & 1.8 & $\begin{array}{l}1.4 \% \text { (up to } 75 \text { years } \\
\text { of age) }\end{array}$ & & \\
\hline$P M S 2$ & & & N.D & N.D & & \\
\hline \multirow[t]{2}{*}{ STK11/LKB1 } & \multirow[t]{2}{*}{$\begin{array}{l}\text { Peutz-Jeghers syn- } \\
\text { drome }\end{array}$} & Pancreatic cyst & 76.2 & $\begin{array}{l}25.6 \% \text { (up to } 70 \text { years } \\
\text { of age) }\end{array}$ & $\begin{array}{l}\text { Lip pigmentation } \\
\text { Gastrointestinal } \\
\text { polyposis }\end{array}$ & \multirow[t]{2}{*}[25,26]{} \\
\hline & & $\begin{array}{l}\text { Intraductal papillary } \\
\text { mucinous neoplasm } \\
\text { Pancreatic cancer }\end{array}$ & & & $\begin{array}{l}\text { Colorectal, gastric, } \\
\text { ovarian, breast, and } \\
\text { cervical cancer }\end{array}$ & \\
\hline \multirow[t]{3}{*}{$A P C$} & \multirow[t]{3}{*}{$\begin{array}{l}\text { Familial adenoma- } \\
\text { tous polyposis }\end{array}$} & Pancreatic cyst & 4.5 & N.D & $\begin{array}{l}\text { Gastrointestinal } \\
\text { polyposis }\end{array}$ & \multirow[t]{3}{*}[27,28]{} \\
\hline & & $\begin{array}{l}\text { Intraductal papillary } \\
\text { mucinous neoplasm } \\
\text { Pancreatic cancer }\end{array}$ & & & $\begin{array}{l}\text { Colorectal and duo- } \\
\text { denal cancer }\end{array}$ & \\
\hline & & & & & Desmoid tumor & \\
\hline \multirow[t]{2}{*}{$C D K N 2 A$} & $\begin{array}{l}\text { Familial atypical } \\
\text { multiple }\end{array}$ & Pancreatic cancer & $13-39$ & $\begin{array}{l}17 \% \text { (up to } 75 \text { years } \\
\text { of age) }\end{array}$ & Malignant melanoma & \multirow[t]{2}{*}[30]{} \\
\hline & $\begin{array}{l}\text { mole melanoma } \\
\text { syndrome }\end{array}$ & & & & Lung cancer & \\
\hline SMAD4/BMPR1A & $\begin{array}{l}\text { Juvenile polyposis } \\
\text { syndrome }\end{array}$ & Pancreatic cancer & N.D & N.D & $\begin{array}{l}\text { Gastrointestinal } \\
\text { polyposis }\end{array}$ & {$[30,31]$} \\
\hline PRSS1/SPINK1 & $\begin{array}{l}\text { Hereditary pancrea- } \\
\text { titis }\end{array}$ & $\begin{array}{l}\text { Acute pancreatitis } \\
\text { Chronic pancreatitis }\end{array}$ & 53 & $\begin{array}{l}40 \% \text { (up to } 70 \text { years } \\
\text { of age) }\end{array}$ & Pancreatitis & {$[32]$} \\
\hline
\end{tabular}

\section{Mismatch repair (MMR) genes (MLH1, MSH2, MSH6, PMS2)}

Defective MMR genes, such as $M L H 1, M S H 2, M S H 6$, and $P M S 2$, display microsatellite instability and are the susceptibility genes of Lynch syndrome [23], a hereditary syndrome associated with an increased predisposition to colorectal, gastric, and endometrial cancers. The accumulated risk of pancreatic cancer in Lynch syndrome is approximately $3.7 \%$, which is slightly lower than that in HBOC [24]. The cumulative incidence of pancreatic 
cancer in MLH1 carriers up to age 75 years is higher (RR 7.8) than that observed for other MMR genes [25].

\section{STK11/LKB1}

The $S T K 11 / L K B 1$ germline variant accounts for approximately $90 \%$ of Peutz-Jeghers syndrome (PJS), which is a hereditary polyposis syndrome with an autosomal dominant pattern of inheritance. PJS patients have increased risk of gastrointestinal and nongastrointestinal cancers and extremely high risk of developing early-onset pancreatic cancer. The cumulative risk for pancreatic cancer is $25.6 \%$ up to the age of 70 years (hazard ratio 76.2), and the mean age of onset is 40.8 (SD 16.2) years [26]. Further, lobular endocervical glandular hyperplasia and peritoneal pigmentation are caused by the STK11 germline variant [27].

\section{APC}

$A P C$ is a well-known susceptibility gene for familial adenomatous polyposis (FAP) [28], a hereditary polyposis syndrome with an autosomal dominant pattern of inheritance. Polyps occur mainly in the colon, but gastric, duodenum, and small bowel polyps are also frequent. The RR for pancreatic cancer is 4.5 times of the general population [29].

\section{Cyclin-dependent kinase inhibitor 2A (CDKN2A)}

$C D K N 2 A$ is a major susceptibility gene for familial atypical multiple mole melanoma syndrome (FAMMM), and FAMMM kindreds are at high risk of developing pancreatic cancer. Individuals with $C D K N 2 A$ variants have a $70 \%$ lifetime risk of developing melanoma and a $17 \%$ risk of developing pancreatic cancer up to the age of 70 years [30]. The RR of developing pancreatic cancer was reported as 13-39 for individuals with mutations in $C D K N 2 A[31,32]$; however, there are no specific screening guidelines for FAMMM.

\section{SMAD4 and BMPR1A}

The SMAD4 germline variant is the most frequently recognized in juvenile polyposis syndrome (JPS), along with the BMPR1A germline variant [33, 34]. Although the RR of pancreatic cancer in JPS is not as high as in other hereditary polyposis syndromes, careful management for preventing pancreatic cancer may be needed.

\section{PRSS1 and SPINK1}

PRSS 1 is encoded by the cationic trypsinogen gene, and SPINK1 encodes the serine protease inhibitor Kazal 1. Hereditary pancreatitis is a rare disease that can progress to chronic pancreatitis. In Japan, the cumulative incidence of pancreatic cancer for hereditary pancreatitis with the PRSS1 and SPINK1 variants was $40 \%$ up to the age of 70 years, and the RR for pancreatic cancer in hereditary pancreatitis was 53 [35].

\section{CPA1 and CPB1}

CPA1 (encoding carboxypeptidase A1) and CPB1 (encoding carboxypeptidase B1) can cause pancreatic acinar cell endoplasmic reticulum (ER) stress and these germline variants may lead to impaired secretion of its protein product and induce ER stress. These variants are more common in patients with pancreatic cancer (approximately $1 \%$ of individuals with pancreatic cancer when compared with $<0.001 \%$ in population controls), suggesting pancreatic acinar cell stress as a potential mechanism of pancreatic cancer susceptibility [36]

\section{Multigene panel testing}

Multigene panel testing is an effective tool for identifying germline pathogenic variants of pancreatic cancer. First, a National Familial Pancreas Tumor Registry (NFPTR; http:// pathology.jhu.edu/pancreas/nfptr/index.php) analysis of the germline DNA of 638 familial pancreatic cancer patients from 593 kindreds revealed that germline pathogenic variants of $A T M, B R C A 2, C D K N 2 A$, and $P A L B 2$ elevated the risk of pancreatic cancer, and that variants of $B U B 1 B, C P A 1$, $F A N C C$, and $F A N C G$ are detected more frequently in familial than in sporadic pancreatic cancer [37]. BRCA2 and ATM germline pathogenic variants are significantly more prevalent in familial pancreatic cancer patients [38]. Furthermore, using linkage analysis, the palladin gene was reported as a new germline pathogenic variant in 2006 [39].

New germline pathogenic variants were described in Japanese familial pancreatic cancer patients [40]. In wholeexome sequencing of germline DNA from whole blood of 81 patients, $A T M$ and $B R C A 2$ were recognized in $7(8.6 \%)$ and $3(3.7 \%)$ patients, respectively. Furthermore, ASXL1 or DNMT3A, which are tumor suppressor genes, were also identified as germline variants of familial pancreatic cancer. Interestingly, new germline susceptibility genes, FAT1 $(n=4)$ and FAT4 ( $n=3)$, which encode the large transmembrane proteins protocadherins, were discovered in seven patients [40]. Therefore, familial pancreatic cancer has a wide range of germline variants instead of a predominant gene such as BRCA1/2 in HBOC or $A P C$ in FAP. Thus, multigene panel testing for pancreatic cancer patients may be able to provide substantial information about high-risk pathogenic germline variants common to previously known hereditary cancer syndromes. 


\section{Low-risk germline variants and environmental factors}

Genome-wide association studies (GWASs) have led to the discovery of common and low-risk germline variants in pancreatic cancer patients. A meta-analysis of GWASs conducted in Europe and the United States reported that an SNV of NOC2L (1p36.33, rs13303010) was significantly associated with pancreatic cancer [41]. A GWAS conducted in East Asia, including Japan and China, reported that an SNV of GP2 (16p12.3, rs78193826), which is common in patients with pancreatic cancer is also strongly involved in KRAS activity [42]. Hence, it is important to recognize the environmental risk factors for pancreatic cancer because they can be modulated/targeted to prevent malignant progression.

\section{Registries for familial pancreatic cancer}

Familial pancreatic cancer is as important as hereditary pancreatic cancer because a family history of pancreatic cancer places an individual at an extremely high risk of pancreatic cancer development. Familial pancreatic cancer was first reported in 1976 in the United States [43], leading to the suggestion of a genetic component. In 1994, the NFPTR was established by researchers in Johns Hopkins University, and prospective registration of familial pancreatic cancer was initiated (Table 2) [44, 45]. Subsequently, the European Registry of Hereditary Pancreatitis and Familial Pancreatic Cancer (EUROPAC, https://www.lctu.org.uk/LCTU_NET/ frontend/Default.aspx?Data=W1tiRzlqWVd4bF1dW09R PT1d) was established in 1997 in the United Kingdom, and the German National Case Collection for Familial Pancreatic Carcinoma (FaPaCa, http://www.fapaca.de/) was introduced in 1999. The PanGen-Fam registry was established in Spain in 2009 to identify families with high PDAC risk [46]. In Japan, the registration system was initiated in 2014 as the Japan Familial Pancreatic Cancer Registry (JFPCR, http:// jfpcr.com/) [47].

The first epidemiological study of NFPTR revealed that the risk in familial pancreatic cancer kindreds was elevated in individuals with three (odds ratio 32.0), two (odds ratio 6.4), or one (odds ratio 4.6) FDR(s) with pancreatic cancer [48, 49]. Next, the large EUROPAC cohort study in 2006 demonstrated that patients with familial pancreatic cancer experienced early onset of pancreatic cancer and were likely to be deceased younger than patients with sporadic pancreatic cancer, which was expressed as anticipation [50]. Third, $\mathrm{FaPaCa}$ showed that $74 \%$ of familial pancreatic cancer has an autosomal dominant inheritance pattern, and familial pancreatic cancer is frequently concomitant with breast cancer [51]. The analysis of the PanGen-Fam registry indicated that family history of cancer and diabetes increased the risk of pancreatic cancer development [52]. Thus, since the risk of developing pancreatic cancer is extremely high in cases with a strong family history, familial and hereditary pancreatic cancer cases should be approached aggressively.

\section{Surveillance for pathogenic germline variant carriers}

Pancreatic cancer has one of the highest mortality rates among all types of malignant solid tumor. The 5-year overall survival is $9 \%-13 \%$ [53], and only approximately $25 \%$ of tumors are resectable [54]. Most patients display no symptoms and undergo rapid progression [55]. Thus, early diagnostic management and intervention is a must for improving outcomes.

The international cancer of the pancreas screening (CAPS) consortium proposed a concise strategy for pancreatic surveillance of high-risk individuals to improve the rate of detection at an early stage [56]. According to CAPS, the best imaging techniques for routine follow-ups are endoscopic ultrasound (EUS) and magnetic resonance imaging or cholangiopancreatography (MRI/MRCP) because of their higher sensitivity and specificity than that of computed tomography $[57,58]$. It is suggested that these screenings should be initiated at the age of 30-35 years or 10 years younger than the earliest exocrine pancreatic cancer diagnosis in the family, especially for patients with PJS [6, 59], but the best timing to start screening of the pancreas for highrisk individuals remains to be established (Table 3) [60].
Table 2 Familial pancreatic cancer registry worldwide

\begin{tabular}{llll}
\hline Registration & $\begin{array}{l}\text { Year of establish- } \\
\text { ment }\end{array}$ & Country & References \\
\hline $\begin{array}{l}\text { National Familial Pancreas Tumor Registry } \\
\begin{array}{l}\text { The European Registry of Hereditary Pancreatitis } \\
\text { and Familial Pancreatic Cancer }\end{array}\end{array}$ & 1994 & United States & {$[19,20]$} \\
$\begin{array}{l}\text { The German National Case Collection for Famil- } \\
\text { ial Pancreatic Carcinoma }\end{array}$ & 1999 & United Kingdom & {$[21]$} \\
$\begin{array}{l}\text { PanGen-Fam Registry } \\
\text { Japan Familial Pancreatic Cancer Registry }\end{array}$ & 2009 & Germany & {$[22]$} \\
\hline
\end{tabular}


Table 3 High-risk individuals for pancreatic cancer

\begin{tabular}{ll}
\hline Subject categories & $\begin{array}{l}\text { Start screening } \\
{[59,62] \text { (age in }} \\
\text { years) }\end{array}$ \\
\hline Three or more first- and/or second- degree relatives with pancreatic cancer & 50 \\
Two or more first-degree relatives with pancreatic cancer & 50 \\
Pathogenic germline variant carrier and a family history of pancreatic cancer (ATM, & 50 \\
BRCA1, BRCA2, MLH1, MSH2, MSH6, EPCAM, PALB2, TP53) & $30-35$ \\
Individuals with pathogenic germline variant in $S T K 11$ & 40 \\
Individuals with pathogenic germline variant in $C D K N 2 A$ & \\
\hline
\end{tabular}

This surveillance is also recommended for individuals with three or more blood relatives with pancreatic cancer, and at least one of those affected FDR carrying the BRCA2 or $P A L B 2$ germline pathogenic variant. Surveillance should be considered for individuals with two affected blood relatives with pancreatic cancer or with at least one FDR [56]. In a 2018 study, during the median 5.6-year follow-up, 14 $(4.0 \%)$ and $10(2.8 \%)$ patients of the 354 high-risk individuals developed pancreatic cancer and high-grade dysplasia, including IPMN, respectively. The resection rate of the pancreatic cancers was $71.4 \%$, and the 5-year overall survival rate was $60 \%$, which is much better than the reported surveillance, epidemiology, and end results in the United States [61]. As this aggressive surveillance has a favorable prognosis, the latest NCCN guidelines also recommend EUS, MRI, and MRCP twice a year for high-risk individuals [62]. It is important to explore other diagnostic modalities including biomarkers to improve outcomes in the near future.

\section{Drug sensitivity}

\section{Poly-ADP-ribose polymerase (PARP) inhibitors}

PARP inhibitors play a key role in the induction of doublestranded breaks after the collapse of the DNA replication process. The efficacy of PARP inhibitors against advanced breast, ovarian, pancreatic, and prostate cancer with a $B R C A 1 / 2$ pathogenic variant was recognized in 2015 [63]. When compared with placebos, PARP inhibitors resulted in longer progression-free survival for $B R C A$-positive metastatic pancreatic cancer following platinum-based chemotherapy [63, 64]. Hence, PARP inhibitors are used as maintenance therapy and $B R C A$ genetic testing for pancreatic cancer is a companion diagnosis.

\section{Immune checkpoint inhibitors}

Pembrolizumab, an immune checkpoint inhibitor, has a critical impact and benefits the survival of patients with germline pathogenic variants of MMR genes [65]. Although only a small proportion (approximately $1 \%$ ) of pancreatic cancer patients have these MMR genes, it is important to assess the potential efficacy of pembrolizumab in hereditary pancreatic cancer [66].

\section{Platinum}

Patients with strong family history of breast, ovarian, and pancreatic cancer have better prognoses than those without such history and are sensitive to platinum-based chemotherapy [67]. However, a prospective Phase II study from Japan revealed that gemcitabine plus oxaliplatin did not produce a favorable outcome in patients with metastatic pancreatic cancer with a family history of breast, ovarian, and pancreatic cancer [68]. BRCA germline pathogenic variants are prognostic and therapeutic biomarkers in breast and ovarian cancer, and platinum-based chemotherapy is a standard treatment for these cancers [68]. As the overall survival for stage-3 or $-4 B R C A$-mutated pancreatic cancer was improved by platinum-based treatment [69], HBOC pancreatic cancer patients are good candidates for platinum-based therapy.

\section{Future perspectives for hereditary pancreatic cancer}

There is no standard conceptualization about the disclosure of germline pathogenic variants. As mentioned earlier, it is possible to detect various types of deleterious variants in the DNA of familial pancreatic cancer patients. These need to be carefully analyzed to decide how to proceed with disease management [70]. Deleterious variants have also been reported in $\sim 5 \%-10 \%$ of patients with apparently sporadic pancreatic cancer $[31,71]$. Because of these papers, recent NCCN guidelines recommend offering genetic testing for patients with newly diagnosed pancreatic ductal adenocarcinoma [62] In addition, optimal surveillance is needed similar to that for HBOC syndrome, because pancreatic lesions are not usually found in routine medical check-ups [72].

It is difficult to predict germline pathogenic variants from a family history of pancreatic cancer. For example, when 306 pancreatic cancer patients were screened for $B R C A$ genetic analysis, 14 (4.6\%) were positive, of which only two 
had family history of pancreatic cancer, indicating that the absence of family history of pancreatic cancer does not mean that BRCA testing should not be performed [73]. BRCA2, $A T M$, and BRCAl were detected, in that order, from blood samples of 1009 pancreatic cancer patients. However, the prediction of germline variants from clinical information such as sex, past medical history, and family history-easy for breast cancer-is extremely difficult for pancreatic cancer [74]. Furthermore, a recent study has revealed that harboring a pathogenic, or likely pathogenic variant is associated with a greater incidence of pancreatic cancer than family history alone (without the presence of an associated germline variant) [75]. Therefore, while hereditary and familial pancreatic cancer overlap in some cases, they must be considered as similar but different domains.

Finally, preventive total pancreatectomy for individuals with $B R C A 1 / 2$ germline pathogenic variants has not been allowed, as it can result in severe and potentially fatal complications, including insulin-dependent diabetes, pancreatic enzyme insufficiency, and blood glucose instability. Conversely, in the recent years, medical developments have led to better control of total pancreatectomy treatment and a trend toward low complication and mortality rates. Therefore, in Europe, it has been suggested that the decision program of prophylactic total pancreatectomy could be useful in high-risk individuals of pancreatic cancers such as hereditary pancreatitis and IPMN with $S T K 11 / L K B 1$ or $C D K N 2 A$ pathogenic variants [76].

\section{Conclusion}

A deeper understanding of hereditary pancreatic cancer is crucial in improving strategies for detecting pancreatic cancer more frequently at an early stage and preventing malignant progression. Multigene panel testing or whole-genome sequencing should be performed for identifying germline pathogenic variants. Continuously updating the current knowledge base of hereditary pancreatic cancer syndromes will aid in the development of potential diagnostic and prognostic measures, resulting in more favorable outcomes.

Acknowledgements We would like to thank Editage (www.editage. com) for English language editing.

Funding This study was funded by Health Labour Sciences Research Grant (20EA1027), Foundation for Promotion of Cancer, Research in Japan, and Daiwa Securities Health Foundation.

\section{Declarations}

Conflict of interest A Hirasawa received lecture fees from Chugai Pharmaceutical Co. Ltd.; Y Kitagawa received lecture fees from Chugai Pharmaceutical Co. Ltd., Taiho Pharmaceutical Co. Ltd., Asahi
Kasei Pharma Co., Otsuka Pharmaceutical Factory Inc., Ono Pharmaceutical Co. Ltd., Tsumura \& Co., Eisai Co. Ltd., Otsuka Pharmaceutical Factory Inc., Medicon Inc., and Takeda Pharmaceutical Co. Ltd.

Open Access This article is licensed under a Creative Commons Attribution 4.0 International License, which permits use, sharing, adaptation, distribution and reproduction in any medium or format, as long as you give appropriate credit to the original author(s) and the source, provide a link to the Creative Commons licence, and indicate if changes were made. The images or other third party material in this article are included in the article's Creative Commons licence, unless indicated otherwise in a credit line to the material. If material is not included in the article's Creative Commons licence and your intended use is not permitted by statutory regulation or exceeds the permitted use, you will need to obtain permission directly from the copyright holder. To view a copy of this licence, visit http://creativecommons.org/licenses/by/4.0/.

\section{References}

1. Yamaguchi K, Okusaka T, Shimizu K et al (2017) Clinical practice guidelines for pancreatic cancer 2016 from the Japan Pancreas Society. Pancreas 46(5):595-604

2. McGuigan A, Kelly P, Turkington RC et al (2018) Pancreatic cancer: a review of clinical diagnosis, epidemiology, treatment and outcomes. World J Gastroenterol 24(43):4846-4861

3. Midha S, Chawla S, Garg PK (2016) Modifiable and non-modifiable risk factors for pancreatic cancer: a review. Cancer Lett 381:269-277

4. Jiao L, Mitrou PN, Reedy J et al (2009) A combined healthy lifestyle score and risk of pancreatic cancer in a large cohort study. Arch Intern Med 169(8):764-770

5. Matsubayashi H, Takaori K, Morizane C et al (2017) Familial pancreatic cancer: concept, management and issues. World J Gastroenterol 23(6):935-948

6. Matsubayashi H (2011) Familial pancreatic cancer and hereditary syndromes: screening strategy for high-risk individuals. J Gastroenterol 46:1249-1259

7. Young EL, Thompson BA, Neklason DW et al (2018) Pancreatic cancer as a sentinel for hereditary cancer predisposition. BMC Cancer 18(697):1-9

8. Pittman ME, Brosens LA, Wood LD (2016) Genetic syndromes with pancreatic manifestations. Surg Pathol 9:705-715

9. Rustgi AK (2014) Familial pancreatic cancer: genetic advances. Genes Dev 28:1-7

10. Ohmoto A, Yachida S, Morizane C (2019) Genomic features and clinical management of patients with hereditary pancreatic cancer syndromes and familial pancreatic cancer. Int J Mol Sci. https:// doi.org/10.3390/ijms20030561

11. Miki Y, Swensen J, Shattuck-Eidens D et al (1994) A strong candidate for the breast and ovarian cancer susceptibility gene BRCA1. Science 266(5182):66-71

12. Goggins M, Schutte M, Lu J et al (1997) Germline BRCA2 gene mutations in patients with apparently sporadic pancreatic carcinomas. Cancer Res 56:5360-5364

13. Wong W, Raufi AG, Safyan RA et al (2020) BRCA mutations in pancreatic cancer: spectrum, current management, challenges and future prospects. Cancer Manag Res 12:2731-2742

14. NCCN Guidelines ${ }^{\circledR}$ genetic/familial high-risk assessment: breast, ovarian, and pancreatic version 1.2021 Pancreatic Cancer Screening (PANC-A) 
15. Rahman N, Seal S, Thompson D et al (2007) PALB2, which encodes a BRCA2- interacting protein, is a breast cancer susceptibility gene. Nat Genet 39(2):165-167

16. Abe K, Ueki A, Urakawa $Y$ et al (2021) Familial pancreatic cancer with PALB2 and NBN pathogenic variants: a case report. Hered Cancer Clin Pract. https://doi.org/10.1186/s13053-020-00160-z

17. Yang X, Leslie G, Doroszuk A et al (2019) Cancer risks associated with germline $P A L B 2$ pathogenic variants: an international study of 524 families. J Clin Oncol 38:674-685

18. Tischkowitz M, Balmaña J, Foulkes W et al (2021) Management of individuals with germline variants in PALB2: a clinical practice resource of the American College of Medical Genetics and Genomics (ACMG). Genet Med. https://doi.org/10.1038/ s41436-021-01151-8

19. Roberts NJ, Jiao Y, Yu J et al (2012) ATM mutations in patients with hereditary pancreatic cancer. Cancer Discov 2:41-46

20. Thompson D, Duedal S, Kirner J et al (2005) Cancer risks and mortality in heterozygous ATM mutation carriers. J Natl Cancer Inst 97:813-822

21. Borecka M, Zemankova P, Lhota F et al (2016) The c.657del5 variant in the NBN gene predisposes to pancreatic cancer. Gene 587:169-172

22. Ruijs M, Verhoef S, Rookus M et al (2010) TP53 germline mutation testing in 180 families suspected of Li-Fraumeni syndrome: mutation detection rate and relative frequency of cancers in different familial phenotypes. J Med Genet 47:421-428. https://doi. org/10.1136/jmg.2009.073429

23. Biller LH, Syngal S, Yurgelun MB (2019) Recent advances in Lynch syndrome. Fam Cancer 18:211-219

24. Bujanda L, Herreros-Villanueva M (2017) Pancreatic cancer in Lynch Syndrome. J Cancer 8(18):3667-3674

25. Seppala T, Latchford A, Negoli I et al (2020) European guidelines from the EHTG and ESCP for Lynch syndrome: an updated third edition of the Mallorca guidelines based on gene and gender. BJS. https://doi.org/10.1002/bjs.11902

26. Korsse SE, Harinck F, Lier MG et al (2013) Pancreatic cancer risk in Peutz-Jeghers syndrome patients: a large cohort study and implications for surveillance. J Med Genet 50:59-64

27. Hirasawa A, Akahane T, Tsuruta T et al (2012) Lobular endocervical glandular hyperplasia and peritoneal pigmentation associated with Peutz-Jeghers syndrome due to a germline mutation of STK11. Ann Oncol 23:2990-2994

28. Nakamura Y, Nishisho I, Kinzler K et al (1992) Mutations of the APC (Adenomatous Polyposis Coli) gene in FAP (Familial Polyposis Coli) patients and in sporadic colorectal tumors. Tohoku J Exp Med 168:141-147

29. Moussata D, Senouci L, Berger F et al (2015) Familial adenomatous polyposis and pancreatic cancer. Pancreas 44(3):512-513

30. Vasen H, Gruis N, Frants R et al (2000) Risk of developing pancreatic cancer in families with familial atypical multiple mole melanoma assoiated with a specific 19 deletion of p16 (p16-leiden). Int J Cancer 87:809-811

31. Hu C, Hart S, Polley E et al (2018) Association between inherited germline mutations in cancer predisposition genes and risk of pancreatic cancer. JAMA 319(23):2401-2409. https://doi.org/10. 1001/jama.2018.6228

32. Vasen H, Ibrahim I, Ponce C et al (2016) Benefit of surveillance for pancreatic cancer in high-risk individuals: outcome of longterm prospective follow-up studies from three European expert centers. J Clin Oncol 34(17):2010-2019

33. Ishida H, Ishibashi K, Iwama T (2018) Malignant tumors associated with juvenile polyposis syndrome in Japan. Surg Today 40:253-263

34. Wain KE, Ellingson MS, McDonald J et al (2014) Appreciating the broad clinical features of SMAD4 mutation carriers: a multicenter chart review. Genet Med 16(8):588-593
35. Masamune A, Kikuta K, Hamada S et al (2018) Nationwide survey of hereditary pancreatitis in Japan. J Gastroenterol 53:152-160

36. Tamura K, Yu J, Hata T et al (2018) Mutations in the pancreatic secretory enzymes CPA1 and CPB1 are associated with pancreatic cancer. Proc Natl Acad Sci USA 115:4767-4772

37. Roberts NJ, Norris AL, Petersen GM et al (2015) Whole genome sequencing defines the genetic heterogeneity of familial pancreatic cancer. Cancer Discov 6(2):166-175

38. Chaffee KG, Oberg AL, McWilliams RR et al (2018) Prevalence of germ-line mutations in cancer genes among pancreatic cancer patients with a positive family history. Genet Med 20(1):119-127

39. Pogue-Geile KL, Chen R, Bronner MP et al (2006) Palladin mutation causes familial pancreatic cancer and suggests a new cancer mechanism. PLoS Med 3(12):2216-2228

40. Takai E, Nakamura H, Chiku S et al (2020) Whole-exome sequencing reveals new potential susceptibility genes for japanese familial pancreatic cancer. Ann Surg. https://doi.org/10.1097/ SLA.0000000000004213

41. Klien A, Wolpin B, Risch $\mathrm{H}$ et al (2018) Genome-wide meta-analysis identifies five new susceptibility loci for pancreatic cancer. Nat Commun 9:556. https://doi.org/10.1038/s41467-018-02942-5

42. Lin Y, Nakatochi M, Hosono Y et al (2020) Genome-wide association meta-analysis identifies GP2 gene risk variants for pancreatic cancer. Nat Commun. https://doi.org/10.1038/ s41467-020-16711-w

43. Friedman JM, Fialkow PJ (1976) Familial carcinoma of the pancreas. Clin Genet 9:463-469

44. Klein AP, Hruban RH, Brune KA et al (2001) Familial pancreatic cancer. Cancer J 7(4):266-273

45. Hruban RH, Canto MI, Yeo CJ (2001) Prevention of pancreatic cancer and strategies for management of familial pancreatic cancer. Dig Dis 19:76-84

46. Mocci E, Guillen-Ponce C, Earl J et al (2015) PanGen-Fam: Spanish registry of hereditary pancreatic cancer. Eur J Cancer 51:1911-1917

47. Morizane C, Kitano M, Hijioka S et al (2017) Japanese familial pancreatic cancer registry with the aim to early detection of pancreatic cancer. Suizo 32(1):23-29

48. Alison KP, Kieran BA, Gloria PM et al (2004) Prospective risk of pancreatic cancer in familial pancreatic cancer kindreds. Can Res 64:2634-2638

49. Tersmette AC, Peterson GM, Offerhaus GJ et al (2001) Increased risk of incident pancreatic cancer among first-degree relatives of patients with familial pancreatic cancer. Clin Cancer Res 7:738-744

50. McFaul CD, Greenhalf W, Earl J et al (2006) Anticipation in familial pancreatic cancer. Gut 55:252-258

51. Schneider R, Slater E, Sina M et al (2011) German national case collection for familial pancreatic cancer $(\mathrm{FaPaCa})$ : ten years' experience. Fam Cancer 11:323-330

52. Molina-Montes E, Gomez-Rubio P, Márquez M et al (2018) Risk of pancreatic cancer associated with family history of cancer and other medical conditions by accounting for smoking among relatives. Int J Epidemiol 47(2):473-483

53. Egawa S, Toma H, Ohigashi $\mathrm{H}$ et al (2012) Japan pancreatic cancer registry; 30th year anniversary. Japan Pancreas Society. Pancreas 41(7):985-992

54. Ansari D, Bauden M, Bergström S et al (2017) Relationship between tumour size and outcome in pancreatic ductal adenocarcinoma. BJS 104:600-607

55. Capasso M, Franceschi M, Rodriguez-Castro KI et al (2018) Epidemiology and risk factors of pancreatic cancer. Acta Biomed 89(9):141-146

56. Goggins M, Overbeek KA, Brand R et al (2020) Management of patients with increased risk for familial pancreatic cancer: updated 
recommendations from the International Cancer of the Pancreas Screening (CAPS) Consortium. Gut 69:7-17

57. Singhi AD, Koay EJ, Chan ST et al (2019) Early detection of pancreatic cancer: opportunities and challenges. Gastroenterology 156:2024-2040

58. Lindquist CM, Miller FH, Hammond NA et al (2018) Pancreatic cancer screening. Abdom Radiol 43:264-272

59. Matsubayashi H, Takaori K, Morizane C et al (2019) Familial pancreatic cancer and surveillance of high-risk individuals. Gut Liver 13(5):498-505

60. Canto MI, Almario JA, Schulick RD et al (2018) Risk of neoplastic progression in individuals at high risk for pancreatic cancer undergoing long-term surveillance. Gastroenterol 155:740-751

61. Yurgelun MB, Chittenden AB, Morales-Oyarvide V et al (2019) Germline cancer susceptibility gene variants, somatic second hits, and survival outcomes in patients with resected pancreatic cancer. Genet Med 21(1):213-223

62. NCCN (2020) NCCN guidelines version 1.2020 pancreatic cancer screening. NCCN (printed on 6 August 2020)

63. Kowalewski A, Szylberg L, Saganek M et al (2018) Emerging strategies in BRCA-positive pancreatic cancer. J Cancer Res Clin Oncol 144:1503-1507

64. Golan T, Hammel P, Reni M et al (2019) Maintenance olaparib for germline BRCA-mutated metastatic pancreatic cancer. NEJM 381(4):317-327

65. Prescribing Information of KEYTRUDA. https://www.accessdata. fda.gov/drugsatfda_docs/label/2017/125514s014lbl.pdf. Accessed 15 Aug 2020

66. Ohmoto A, Yachida S, Morizane C (2019) Genomic features and clinical management of patients with hereditary pancreatic cancer syndromes and familial pancreatic cancer. Int J Mol Med 20(561):1-16

67. Fogelman D, Sugar EA, Oliver G et al (2015) Family history as a marker of platinum sensitivity in pancreatic adenocarcinoma. Cancer Chemother Pharmacol 76:489-498

68. Okano N, Morizane C, Nomura S et al (2020) Phase II clinical trial of gemcitabine plus oxaliplatin in patients with metastatic pancreatic adenocarcinoma with a family history of pancreatic/breast/ ovarian/prostate cancer or personal history of breast/ovarian/prostate cancer (FABRIC study). Int J Clin Oncol 25(10):1835-1843

69. Golan T, Kanji ZS, Epelbaum R et al (2014) Overall survival and clinical characteristics of pancreatic cancer in BRCA mutation carriers. Br J Cancer 111:1132-1138

70. Kaufman B, Shapira-Frommer R, Schmutzler RK et al (2015) Olaparib monotherapy in patients with advanced cancer and a germline BRCA1/2 mutation. J Clin Oncol 33(3):244-250

71. Shindo K, Yu J, Suenaga M et al (2017) Deleterious germline mutations in patients with apparently sporadic pancreatic adenocarcinoma. J Clin Oncol 20(35):3382-3390

72. Richards S, Aziz N, Bale S et al (2015) Standards and guidelines for the interpretation of sequence variants: a joint consensus recommendation of the American College of Medical Genetics and Genomics and the Association for Molecular Pathology. Genet Med. https://doi.org/10.1038/gim.2015.30

73. Holter S, Borgida A, Dodd A et al (2015) Germline BRCA mutations in a large clinic-based cohort of patients with pancreatic adenocarcinoma. J Clin Oncol 33(28):3124-3129

74. Mizukami K, Iwasaki Y, Kawakami E et al (2020) Genetic characterization of pancreatic cancer patients and prediction of carrier status of germline pathogenic variants in cancer-predisposing genes. EBio Med. https://doi.org/10.1016/j.ebiom.2020.103033

75. Abe T, Blackford A, Tamura K et al (2019) Deleterious germline mutations are a risk factor for neoplastic progression among highrisk individuals undergoing pancreatic surveillance. J Clin Oncol 37:1070-1080. https://doi.org/10.1200/JCO.18.01512

76. Scholten L, Latenstein A, Aalfs C et al (2020) Prophylactic total pancreatectomy in individuals at high risk of pancreatic ductal adenocarcinoma (PROPAN): systematic review and shared decision-making programme using decision tables. UEG J 8(8):865-877

Publisher's Note Springer Nature remains neutral with regard to jurisdictional claims in published maps and institutional affiliations. 